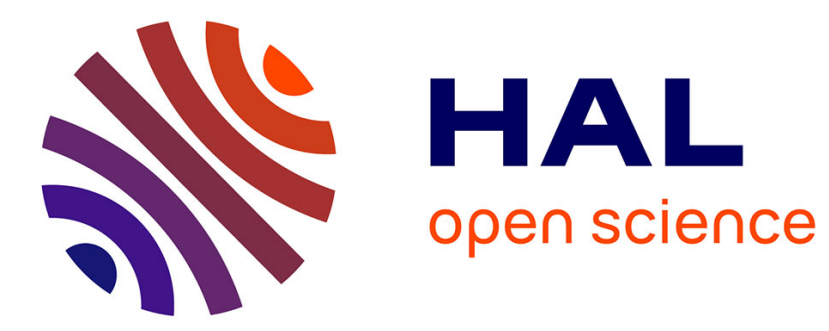

\title{
Spherical wave interaction with cylindrical holes in large limestone specimens
}

\author{
R. Klopp, A. Florence, J. Simons, J. Gran
}

\section{To cite this version:}

R. Klopp, A. Florence, J. Simons, J. Gran. Spherical wave interaction with cylindrical holes in large limestone specimens. Journal de Physique IV Proceedings, 1994, 04 (C8), pp.C8-735-C8-740. 10.1051/jp4:19948113 . jpa-00253355

\section{HAL Id: jpa-00253355 https://hal.science/jpa-00253355}

Submitted on 1 Jan 1994

HAL is a multi-disciplinary open access archive for the deposit and dissemination of scientific research documents, whether they are published or not. The documents may come from teaching and research institutions in France or abroad, or from public or private research centers.
L'archive ouverte pluridisciplinaire HAL, est destinée au dépôt et à la diffusion de documents scientifiques de niveau recherche, publiés ou non, émanant des établissements d'enseignement et de recherche français ou étrangers, des laboratoires publics ou privés. 


\title{
Spherical wave interaction with cylindrical holes in large limestone specimens
}

\author{
R.W. Klopp, A.L. Florence, J.W. Simons and J.K. Gran
}

SRI International, 333 Ravenswood Ave., Menlo Park, CA 94025, U.S.A.

\begin{abstract}
Resumé: On a mesuré dans du calcaire séché la fermeture de cavités cylindriques soumises à des trajectoires de déformation identiques par onde sphérique divergente ou compression quasistatique. L'onde sphérique est produite par une charge explosive et le chargement quasi-statique par une machine de compression triaxiale. Les fermetures maximales dans l'axe de chargement (crown-invert) sont presque égales, à part que l'on enregistre un rebond important dans l'essai dynamique et négligeable dans l'essai statique. La fermeture dans la direction perpendiculaire à l'axe de chargement (springline) est six fois plus grande pour le cas statique que pour le cas dynamique. Des coupes post-mortem de l'échantillon montrent dans les deux cas des "bandes de cisaillement" hyperboliques se propageant dans la roche adjacente à la cavité perpendiculairement à l'axe de chargement.
\end{abstract}

\begin{abstract}
The closure of cylindrical holes in dry limestone was measured for spherically divergent stress wave loading and for quasi-static compression loading with the same strain path. The sperical wave was produced with an explosive charge. The quasi-static loading was produced in a triaxial compression machine. The dynamic and static crown-invert peak closures were approximately equal but significant rebound was recorded in the dynamic test whereas rebound was negligible in the static test. The static springline closure was six times the dynamic springline closure. Posttest cross sections through the test specimens revealed hyberbolic "shear bands" extending from the holes at the springline into the surrounding rock for both types of loading.
\end{abstract}

\section{INTRODUCTION}

The dynamic closure of cylindrical holes in rock by divergent stress waves is an important practical problem. Previous laboratory studies of hole closure have been reported [1], but only for uniaxial loading at quasistatic rates. We performed laboratory experiments to obtain the dynamic hole response to divergent loading and compared it with the quasistatic hole response to the same loading, with loading defined in terms of free-field strain path. The tests were performed in dry Indiana limestone containing about $14 \%$ porosity, with a density of about $2.3 \mathrm{~g} / \mathrm{cm}^{3}$ and having an unconfined crush strength of $50-60 \mathrm{MPa}$.

\section{DYNAMIC TEST}

The overall layout of the dynamic test is shown in Figure 1. Briefly, two large (1.2-m-diameter, 0.76-m-high) octagonal prisms of limestone are stacked one atop the other. Mating hemispherical cavities in the adjoining faces of the prisms contain a spherical, 111-g PETN charge. In the horizontal plane of the charge, on the upper surface of the lower prism are placed 17 circular wire loop particle velocity (PV) gages 


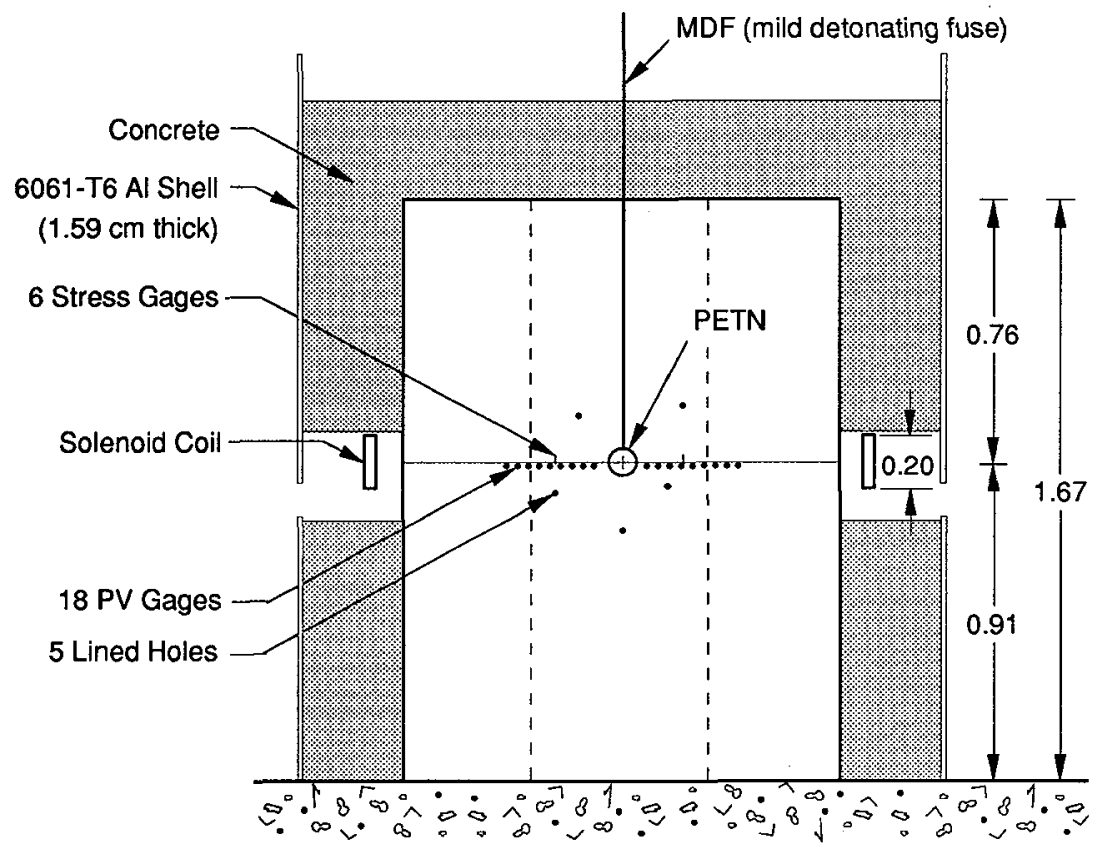

(a) Vertical cross section
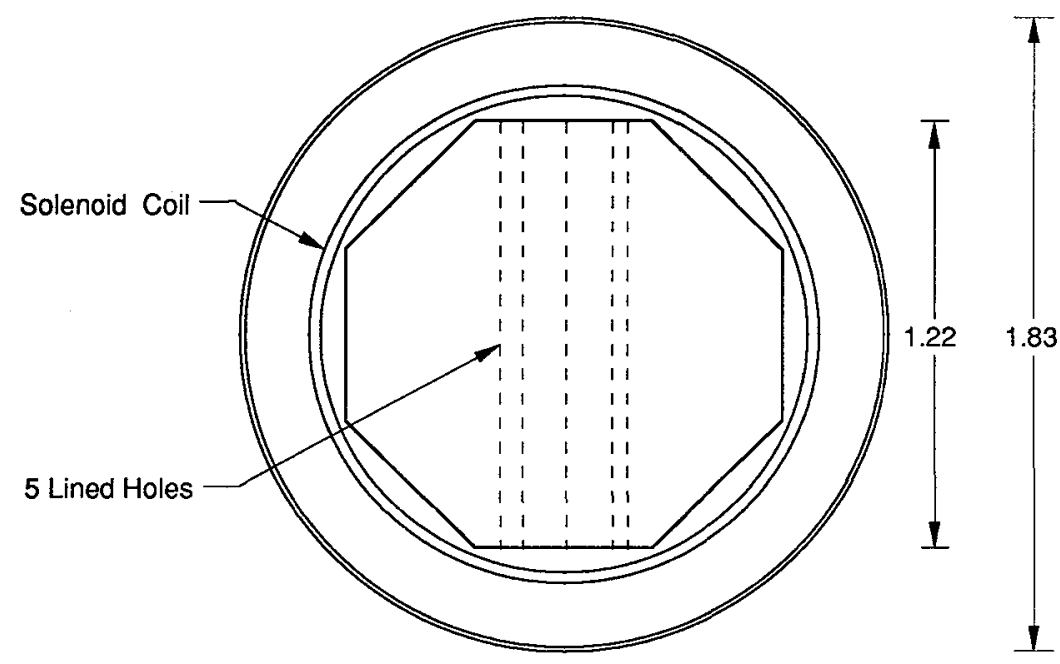

(b) Plan View

Figure 1. Dynamic test configuration. Measurements in meters. 
glued into grooves in the stone concentric with the charge cavity. The PV gages are driven by a solenoid coil that surrounds the specimen stack. When the PV gages move in the solenoid magnetic field, each generates an electromotive force (EMF) proportional to the field strength and loop circumference, which are known beforehand, and the radial velocity. The PV gage technique is a large-size version of the method developed by Florence et al. [2], which is similar to a PV gage technique used by Larson [3] to monitor spherical waves in a variety of geologic materials.

Five 20-mm-diameter, straight, parallel, cylindrical holes were drilled through the prisms parallel to the charge plane. The holes were fitted with aluminum 3003-H0 liners, which were in close contact with the rock but not bonded to it. The three holes drilled in the lower prism were instrumented with fiber-optic gages to measure the dynamic crown-invert (along a ray from the charge) and springline (transverse to a ray from the charge) hole closure histories. One hole was located such that the shortest distance between the hole axis and the charge was $14.5 \mathrm{~cm}$, and the other two were located such that this distance was $19.2 \mathrm{~cm}$. The 14.5- and 19.2-cm ranges correspond to approximately the 200-MPa and 120-MPa radial stress ranges, respectively.

We obtained excellent free-field particle velocity and hole closure measurements in the dynamic test. The particle velocities reproduced those obtained in an earlier test within about $10 \%$. The closure records of the two holes at the $120-\mathrm{MPa}$ range were within $10 \%$ as well. Particle velocity records are shown in Figure 2. Circumferential strains were obtained by integrating the velocities to obtain displacements and dividing by the gage radius, then averaging adjacent gage records to obtain the strain at the midpoint between gages. Radial strains were obtained by subtracting adjacent gage records and dividing by the distance between them.

\section{STATIC TESTS}

The static test specimen is a circular cylinder $30 \mathrm{~cm}$ in diameter and $45 \mathrm{~cm}$ high with a $20-\mathrm{mm}$ diameter hole drilled perpendicularly through the cylinder axis at mid height. The hole is lined as in the dynamic tests and is fitted with the same fiber-optic closure gages. The cylinder is fitted with gages to measure vertical and horizontal strains and with soft copper caps and a membrane to prevent the fluid that loads the specimen from entering the pores of the rock. The cylinder is placed in a hydraulic triaxial testing machine that applies independent axial and radial pressures to the cylinder. The static axial pressure and axial strains correspond to the dynamic radial stresses and strains, respectively, and the static radial pressures and circumferential strains correspond to the dynamic circumferential stresses and strains. During the static test, the axial and radial pressures were controlled to trace the preexisting dynamic strain path for the 19.2-cm distance from the charge.

\section{RESULTS AND DISCUSSION}

The static and dynamic strain paths are shown together in Figure 3. Along the paths are indicated points chosen to represent equivalent times in the two tests. The dynamic test times are chosen as the basis.

Static and dynamic hole closures are compared in Figure 4. Static and dynamic peak crown-invert closures are similar, but the equivalent time to reach the peak is longer in the dynamic test, i.e., the peak dynamic closure occurs farther along the strain path. Following the peak, the dynamic closure rebounds to about half the peak level, whereas the static closure rebounds only slightly. The static and dynamic springline closures differ significantly throughout their histories.

The specimens were sectioned perpendicular to the holes posttest. The overall damage mechanism for the holes in the two tests is similar: hyperbolic shear bands and/or cracks extend away from the hole springlines, as shown in Figure 5. The patterns differ somewhat in detail: the dynamic bands are tangent to the hole liner at the springlines, whereas the quasistatic bands are offset from the liner by about one-tenth of a hole diameter and there is a region of crushed rock around the springlines that extends from the liner to the outside surface of the shear bands. The dynamic bands are more irregular and cracklike. The band pattern suggests that the crown and invert move toward each other at the tips of relatively undeformed wedges of rock that impinge at the springlines to form rubble zones.

There are clear differences between the static and dynamic hole closure response. Generally, the dynamic closure is smaller and delayed with respect to progress along the free-field strain path. The differences can be attributed to two effects: rate dependence of the material properties and inertia. A dynamic test in which the specimen remained fully elastic would show oscillatory closure histories and complete rebound, albeit occurring at a higher frequency than shown in Figure 4. Thus, inertia is probably largely responsible for the rebound of dynamic crown-invert closure in our test, too. Rate dependence of 


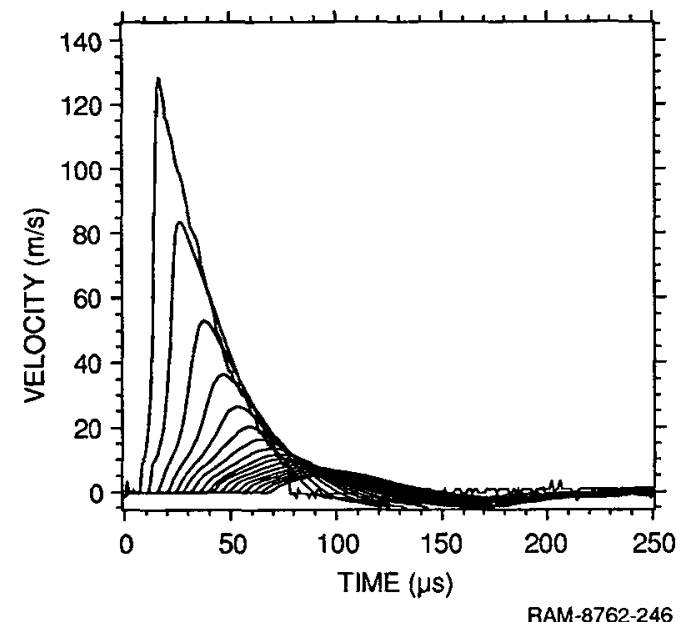

Figure 2. Measured free-field particle velocities at ranges from 6.67 to $33.33 \mathrm{~cm}$ at $0.83-\mathrm{cm}$ intervals.

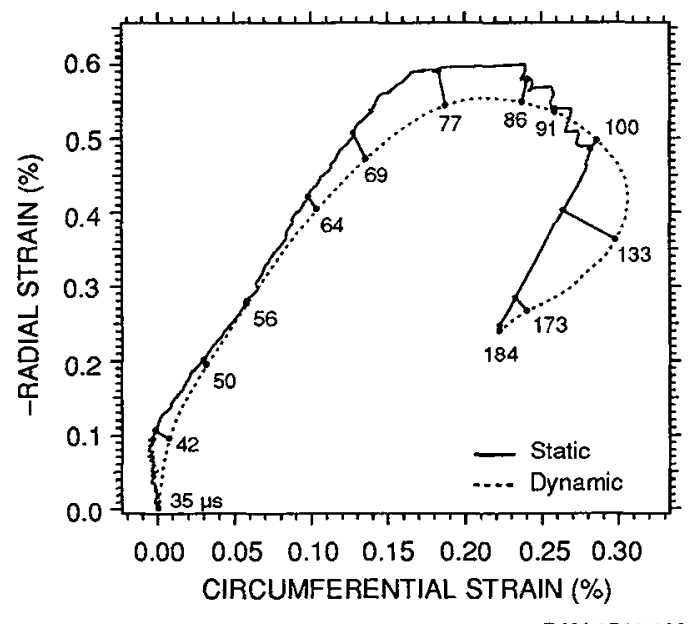

Figure 3. Comparison of quasistatic and dynamic strain paths. Equivalent times ( $\mu \mathrm{s})$ are indicated along the paths.

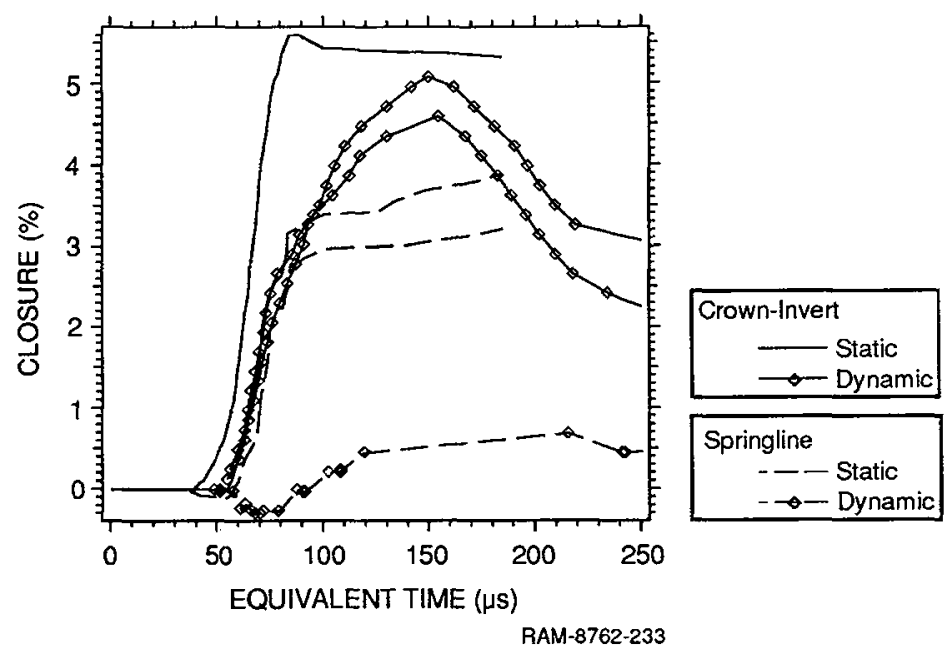

Figure 4. Comparison of static and dynamic closures of $120-\mathrm{MPa}(19.2-\mathrm{cm})$ range holes. 


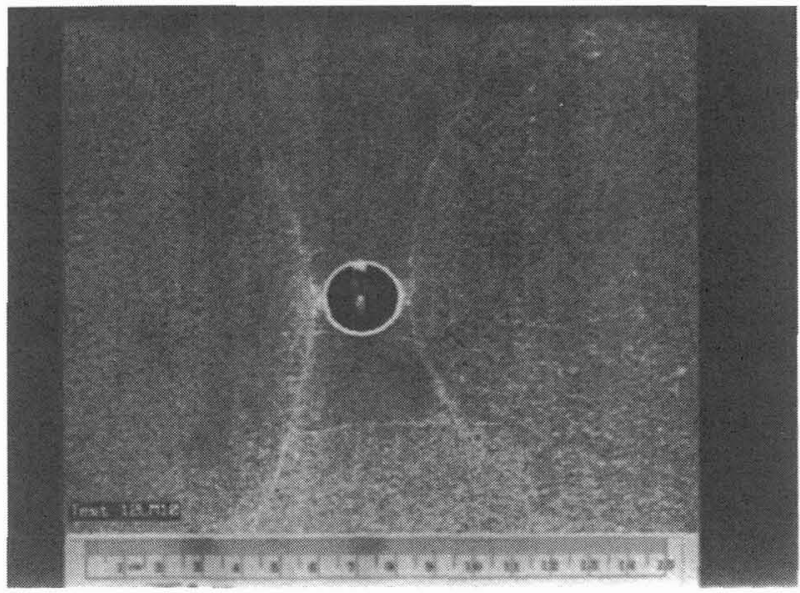

(a) Static

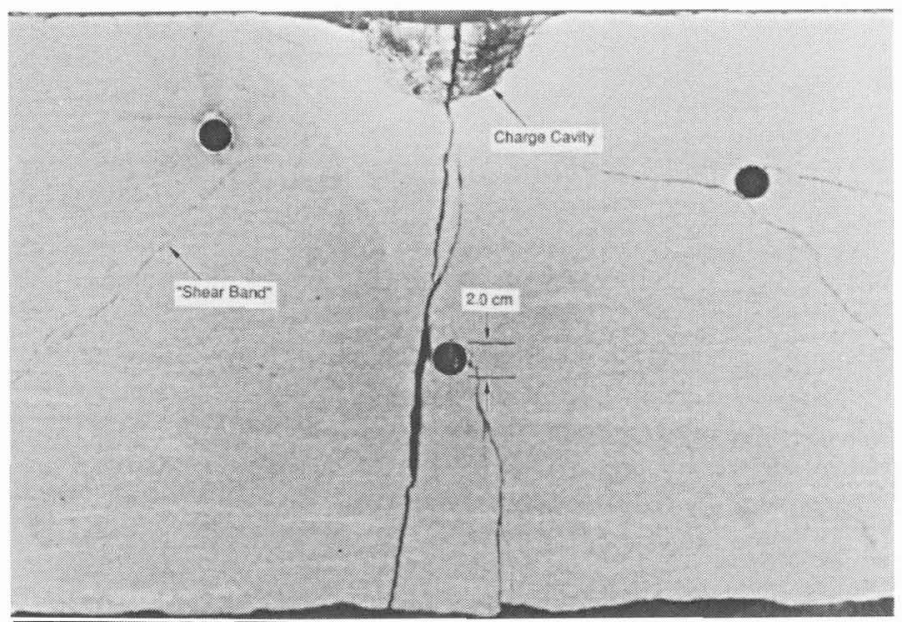

(b) Dynamic

RPM-8762-242A

Figure 5. Cross-section showing posttest damage around the hole. 
rock strength is largely responsible for the differences in final closures and in springline damage, because the material in both tests was exercised along very similar free-field strain paths. Both inertia and rate dependence may be responsible for the relative delay of dynamic closure in terms of arc length along the strain path. However, since the free-field response at the 19.2-cm distance from the charge is elastic or nearly so, the time delay is probably due mainly to inertia.

Acknowledgment: This research was conducted under Contract DNA 001-90-C-0032 with the Defense Nuclear Agency. We thank the technical monitor, Dr. Paul E. Senseny, for many fruitful discussions.

\section{REFERENCES}

1. Simons, J. W., Colton, J. D., and Florence, A. L., "Laboratory testing of scale model intersections," in Scale Effects in Rock Masses, Proceedings 1st International Workshop on Scale Effects in Rock Masses, Loen, Norway, June 1990 (Rotterdam, A. A. Balkema, 1990) pp. 253-259.

2. Florence, A. L., Cizek, J. C., and Keller, C. E., "Laboratory experiments on explosions in geologic materials," in Shock Waves in Condensed Matter - 1983, (Amsterdam, Elsevier, 1984) pp. 521-524.

3. Larson, D. B., "Explosive energy coupling in geologic materials," Int. J. Rock Mech. Min. Sci. Geomech. Abstr. 19 (1982) 157-166. 